\title{
Marriage Agreements Post Decision of Constitutional Court No 69 Puu / Xiii / 2015 Human Rights Perspective
}

\author{
Nurul Miqat ${ }^{1} \quad$ Anwar Borahima $^{2} \quad$ Farida Patittingi $^{2} \quad$ Hasbir Paserangi ${ }^{3}$ \\ 1. Doctoral Student, Faculty Of Law, Hasanuddin University, Indonesia \\ 2. Professor Of Law, Faculty Of Law, Hasanuddin University, Indonesia \\ 3. Lecturer Of Law, Faculty Of Law, Hasanuddin University, Indonesia
}

\begin{abstract}
In Indonesia Marriage Law is accomadated into Law No. 1 of 1974 Concerning Marriage ( Law of Marriage 1974) All Provisions concerning marriage shall be governed there in, the enactment of such provision, resulting in any provisions concerning marriage which have been imposed by some previous laws, shall be deemed invalid, in accordance with the lex posterior legi priori principle. no exception, concerning property of husband and wife in the matter of wealth management, marriage law provides space for marriage couple to make an agreement on allotment of marriage property, has been determined by Law of Marriage 1974 that, every prospective bride, will be marriage men and women are allowed to make a marriage agreement, before the marriage or at the time of the ongoing branding. The vardict of the Constitutional Court No. 69 PUU/XIII/2015 make a new decition by giving more space to the married couple that marriage agreement can be made in marriage. the constitutional Court's decision provides a space for couple to make a marriage agreement, becuase one of the impacts is for mixed marriages, mixed marriage couples who do not make marriage agreements due to their ignorance of the time when the drafting of the marriage agreement, the partners cannot own land in Indonesia, due to the unification of marital property, and the prohibition of foreign nationals from owning land in Indonesia, there was a judicial review of the time marriage agreement was made, and the judge handed down a decision that the marriage agreement could be made while the was ongoing, the ruling gave a fresh breath to the couple husbnad and wife who will make a marriage agreement, especially for mixed marriage. Marriage law 1974 considered to have accommodated the interests of human rights, some rules specified in the Marriage Law in line with interests of human rights.
\end{abstract}

Keywords : Marriage Agreement, Human Rights.

DOI: $10.7176 / J L P G / 94-08$

Publication date: February $29^{\text {th }} 2020$

\section{A. INTRODUCTION}

Marriage is a sacred bond between a man and a woman who accepts the consent to submit to the Marriage Law namely Law No. 1 of 1974 concerning marriage. Character Zoon Politicon people who are destined to always live in groups in a cluster called the community ${ }^{1}$. Living in groups, then attracting each other, is natural, attraction to one another, not only emotionally interested, but interested in forming a family under the auspices of the law, that is what is called marriage.

The long debate to give birth to a unification of marriage law, has taken a long time, in Indonesia recognized 3 marriage legal system, namely adat marriage, Islamic marriage law, and marriage law according to Book of civil law. Finally on December 22, 1973, the People's Representative Council (PRC) approved the 1973 Marriage Bill (MB 1973) into Law, and on January 2, 1974, the Government has promulgated it in the State Gazette of the Republic of Indonesia Number 1 of 1974 under the name of Law of the Republic of Indonesia Number 1 Year 1974 on Marriage (Law of Marriage).

Entry into force of this Act then ends marriage rules other than those set forth in the LM 74.

With the enactment of the LM of 1974, it became the spear of the Law of marriage and was a rule that should be subdued by it in terms of marriage. Nevertheless, Law No. 1 of 1974 still provides little problems for certain circles, this is marked by several requests for submission of review to the Constitutional Court by some who feel has been harmed by some of the articles contained therein. The first example, the first examination of Polygamy Article submitted by M. Insa, an entrepreneur from Bintaro Jaya, South Jakarta. Isna applies for the examination of several Articles and considers that the Articles, among others, Article 3 (1) and (2), Article 4 paragraph (1) and (2), Article 5 paragraph (1), Article 9, Article 15, and Article 24 of the Marriage Law has reduced the right to freedom of worship according to its religion, namely to worship polygamy. According to Ina, the provisions of the Article have supported their preoregative rights in marriage by having to ask permission to the wife if they want to have polygamy ${ }^{2}$. secondly, the examination of Article 2 paragraph (2) and Article 43 paragraph (1) of the marriage law filed by Aisyah Mochtar, singer artist on the relationship of the child's extraborn with his biological

\footnotetext{
${ }_{1}^{1}$ Moch. Isnaeni. 2001. Hukum perkawinan Indonesia. Revka Petra Media: Surabaya.

${ }^{2}$ Decision of Constitutional Court Nomor 12./ PUU-V/ 2017
} 
father.

Some submission of the review against some articles in the Law 1974, indicates that the law still has not accommodated the interests of the people of Indonesia. And the last is the Constitutional Court ruling, the Constitutional Court (CC) allows married couples to make the Marriage Agreement.

The Marriage Agreement is an act committed by a spouse who wishes to enter into an or deal by entering into an agreement set forth in an agreement which shall then be endorsed by the General Officer before the Verdict of the Constitutional Court NO. 69 / PUU / XIII / 2015, the prospective husband and the future husband the marriage partner, if wishing to enter into a marriage agreement, must be done at the time before the marriage takes place, or at the time of marriage in progress and immediately listed. However, based on the submission of a judicial review by Ida Farida who filed a review against one of the Articles in the Marriage Law namely Article 29, then the marriage agreement can be done throughout the marriage.

The normative value that evolves from the value of the source value component is the rule of law of a society. Thus, the law that the judges intend to uphold through judicial functions and authorities is all the normative values contained in the rules of law and which derive from the values of religious, moral, economic, cult, custom and fair decency. ${ }^{2}$

Likewise in the view of human rights issues (human rights) that can always enter into all aspects of life. Always the topic of the actual conversation, And always discussed in order to get the solution, the debate in human rights can always be done in various reasons, and various unequal topics about:

a. Human rights are the rights of all those who are associated with the recognition of human dignity which is sometimes naive and not enjoyed by every human being in the world;

b. Human rights are a natural human right which in certain cases is denied by other human beings, for various reasons and differences

c. There is a denial of human rights by a tribe / nation, a particular Country against another because of different interests;

d. The occurrence of human rights violations within a certain period of time or for long periods of time due to unilateral reasons that resulted in the destruction of a living order within a particular area;

e. Human rights must be fought on an ongoing basis, given the unequal understanding in various layers and places.

Context of the concept of marriage agreement, the rights of marriage contractors must be accommodated by human rights, violation or non-fulfillment of rights in marriage agreement must be relevant to human rights.

Based on the Introduction that has been described above, the authors draw conclusions to be studied, namely how the marriage agreement Post-Decision of the Constitutional Court No. 69 / PUU-XIII Year 2015, Human Rights Perspective.This research is expected to provide the following benefits: Theoretical benefits, increase knowledge, insight and understanding of Marriage Agreement Post-Decision of Constitutional Court, Perspective Human Rights. Practical Benefits, the results of this paper is expected to be useful as input for legal practitioners and citizens who will make a marriage agreement.

\section{B. RESEARCH METHODS}

This research is normative law research, normative law research ${ }^{3}$ is law research which put law as a system norm. The norm system is about principles, norms, rules of legislation, court decisions, agreements and doctrines. ${ }^{4}$

In normative legal research does not recognize the existence of data, to solve legal issues and at the same time to provide prescriptions of what should be, required sources of legal research. Legal sources of legal research can be distinguished into legal research resources in the form of legal materials of primary law materials and secondary legal materials.

\section{RESULT AND DISCUSSION}

a. Marriage Agreement Post the Constitutional Court Decision No. 69 / PUU-XIII Year 2015 Human Rights Perspective

Living in clusters with complex interactions between members in order to fulfill the natural needs of life, forming values in order to preserve the essence of its existence, which is the result of crystallizing the ongoing routine of relations between community members. ${ }^{5}$

Cicero gives a picture of the biological nature of human beings who are zoon politicon, gave birth to adagium ubi societas, ibi ius, no society without law, and likewise also there will be no law without society. ${ }^{6}$

\footnotetext{
1 Decision of Constitutional Court Nomor 46/ PUU-VIII/ 2017

2 Ahmad Mujahidin. 2009. Hakekat, Konsep Dan Implikasi Dalam Perspektif Hukum Masyarakat, Refika Aditama: Bandung.

3 Peter Mahmud Marzuki, 2015, penelitian hukum, Prenadamedia Grup: Jakarta

${ }^{4}$ Mukti Fadjar and yulianto achmad, 2015, dualisme penelitian hukum normative dan empiris, Pustaka Pelajar: Yogyakarta,

${ }^{5}$ Moch Isnaeni. 2016. Asas Hukum Perkawinan. Refika Petra Media: Surabaya.

${ }^{6}$ Ibid.
} 
Marriage is a bond between a man and a woman to a legal bond called marriage, because of the bond it will have a status that is held by the man to become your husband and the woman becomes a wife. In Indonesia itself before the entry into force of the Unification on Marriage regulations, three marriage laws apply, namely, Islamic marriage law, customary marriage law, and Western marriage law.

Prior to the enactment of the LM 1974, there have been various laws and regulations governing the matter ${ }^{1}$, the laws and regulations governing the marriage and civil marriage of the Bumi Putra Christians:

1. Staatsblad 1840 Number 2, the rules governing the registration of births, marriages and deaths for the Christian community of Depok and Tugu, but do not contain the material of marriage law.

2. Reglement Voor Inlandsche Christenen in het Gouvernement der Moluksche Eilenden Op het Aangaan Van Huwelijken zoo onderling als met Europeanen of Zalver afstammelingen afstammelingen dated 24 May 1861 Ind.S. 1861 No.38, then underwent several changes. The Reglement is commonly called the Huwalijkse Reglement Molukse, which prevails in Manado, Ternate, Ambon areas. Basically its own Law of Marriage marriage remains never regulated in those regimes. The colonial government only establishes its formal law, whereas the material law is fully determined by local customary law.

3. The area which is the rest of the archipelago areas shall apply the provisions of S. 1864 No. 142 which was then supplemented with S. 1885 No. 185, also part of this Reglement applies in areas not controlled by the Moluksche Huweljiks Reglement and the provisions of S 1993 N0.74, essentially the same as the Moluksche Huwelijksche Reglement does not govern the material of its marriage law.

The mentioned regulations basically only deal with limited civilian records, not providing a complete picture of marriage law. In the archipelago at the time of the Dutch ruling, some marriage laws apply. the diversity of the law of marriage is indeed in line with the distribution of population groups in the Dutch East Indies on the basis of Article 131 Jo 163 IS (Indische Staatsregeling).

Pancasila as the basis of the State is the basis of reference to make legal unification of marriage, in 1974 finally the government enacted Law No. 1 of 1974 on marriage hereinafter referred to as LM 74, effective from 1 October 1975 after the issuance of Government Regulation No. 9 Year 1975 concerning the implementation of Marriage Law Number 1 Year 1974.

Therefore, "for marriage and all things related to marriage, after the coming into effect of Law Number 1 Year 1974, all the provisions set forth in the Civil Code, and other Regulations governing marriage, if it is regulated in this Law, not be applied any more" to the principle lex posterior derogate legi priori, the new provision override the old provisions.

The marriage according to the Law No.1 year 1974 is contained in Article 1 affirming "Marriage is the inner bond between man and woman as husband and wife with the aim of forming a happy and eternal family (household) based on Supreme Selflessness" in the definition it is contained meaning that the State describes the meaning of the marriage itself. Compared to the definition of marriage contained in the Civil Code, it can be seen in Article 26 of the Civil Code which states that "The law views matters of marriage only in civil relations" essentially the relationship between men and women is limited to ordinary civil relationships. While in the Marriage Law the religious element is very thick, because marriage other than the bond of a man and a woman, marriage also concerns the business of worship with God. Seen also in Article 2 of the Marriage Law which expressly provides the provision:

The requirement of marriage is very dependent on the spiritual / religious element, the marriage process in Indonesia its validity depends on each religion embraced by the couple who will make the marriage.

The legal consequence of a marriage, that is, a man and a woman are bound in a marriage and are attached to the responsibility of a husband and as a wife, besides that there is another law effect following the marriage, one of which is to marriage, the legal consequences of marital property are mentioned in Article 35 of the Marriage Law. However, to this marriage property, can be set aside the arrangement as long as the husband or wife is making a marriage agreement.

Customary law does not recognize the marriage agreement, the Civil Code (Civil Code) characterizes the marriage agreement is individual, and capitalist, because in the marriage agreement by the Civil Code recognizes the individualistic of the property of each husband and wife. The capitalist aspect is to secure the household from the bankruptcy, bankruptcy in business, meaning that if one party, both husband and wife fall into bankruptcy, others can be saved. ${ }^{2}$

Costumary law wich is an written law product controls the law of lands before the coming into Agrarian Basic Law (UUPA ) in costumary Law itself also regognizes the right of land rights, the relationship life between human

\footnotetext{
${ }^{1}$ Van Vollenhoven dalam Soetojo Prawirohamidjojo, Pluralisme dalam Perundang-undangan Perkawinan Di Indonesia, 2006, Airlangga University Press, Surabaya

${ }^{2}$ R. Soetojo Prawirohamidjojo, Pluralisme Dalam Perundang-Undangan Perkawinan Di Indonesia, 2006, Airlangga University Press: Surabaya
} 
beings that are orderly arrangement and related to each other side of the land becomes the place of the ancestors, such a thing is rooted in the nature of their thoughts. ${ }^{1}$

For married couples who want to avoid the uniform mixing of property in marriage, the Law provides the means, namely by making a special agreement, called the marriage agreement (Article 139 of the Civil Code). The marriage agreement is an agreement concerning the property or of the beheer of the marriage property. A marriage agreement is required if the prospective husband and wife at the time of going to marrisage already has property or during the marriage they expect a new acquisition of wealth.

Article (147) The Civil Code of the marriage agreement shall be made in a certain form, which shall be made in notaril. It must be made or done before marriage and can not be changed. Whereas according to the Marriage Act of 1974 on Marriage, marriage agreements may be made before marriage and at the time of marriage takes place.

Marriage Agreements In Indonesia are agreements made by prospective husbands and future wives, before marriage takes place and authorized by a Marriage Officer (MO), the Marriage Agreement law itself is based on:

1. Civil Code

2. Law Number 1. Year 1974 and Government Regulation No. 9 of 1975 on Implementation of Act number 1. Year 1974.

3. Compilation of Islamic law

The provisions of the marriage agreement are stipulated in Act number 1 of 1974, the provisions concerning the marriage agreement are set forth in Chapter V Article 29 consisting of four verses namely:

Paragraph (1) at the time or before the marriage takes place, both parties to mutual consent may enter into a written agreement authorized by the marriage registry officer, after which the content also applies to third parties as long as the third party is involved. Paragraph (2) of the agreement shall not be enacted if it violates the boundaries of law, religion and morals. Paragraph (3) of the agreement is valid since the marriage takes place. Paragraph (4) during the marriage takes place the treaty can not be changed, unless from both sides there is agreement to change and change not to harm a third party.

K. Wantjik Saleh ${ }^{2}$ gives the interpretation of the Article the scope of the marriage agreement is not specified what the agreement is about, for example about property. Since there is no such restriction, it can be concluded that the agreement is immense, may concern various matters, in the explanation of that article which can be said that the meaning of the agreement does not include ta'lik talak.

The decision of the Constitutional Court No. 69 PUU / XIII / 2015 allows the Marriage Agreement to be made when the couple has become husband and wife (couples). The Court judged it to prevent things that are not desirable. The Marriage Agreement is governed by Article 29 paragraph 1 of Law No. 1 of 1974 concerning Marriage, which reads: At the time or before the marriage takes place, the two parties to mutual consent may enter into a written agreement authorized by the marriage registry officer, after which the content also applies to third parties as long as the third party is involved 'The Court considers the above article to be contradictory to the 1945 Constitution. The Panel of Judges decides the "provisions" at or before the marriage take place "in Article 29 paragraph (1) and the provisions of' during marriage take place 'in Article 29 paragraph (4) 1/1974 is contradictory to the 1945 Constitution as long as it is not understood including also during the marriage bond. The Constitutional Court's ruling is an expected ruling by the husband of the wife, especially those who filed a lawsuit against articles that are considered to violate their rights to marital property, the value of hustice is also a form of action referred to in Quran, in the view of the expert usus Fiqhi stated that the word $A L A d l$ in Surah An Nahl verse 90 is a direct order that must be carried out. ${ }^{3}$

In a husband and wife relationship as a family in addition to the rights and duties of husband and wife, there will be many disputes over property issues as well as one of the factors that can lead to various disputes or tensions within a marriage. The problem of property is not impossible to eliminate the harmony between husband and wife in the life of a family.

The Constitutional Court assessed the purpose of the revision of the article so as to avoid any imbalances, such provisions include:

1. Separating wealth between husband and wife so that their property is not mixed. Therefore, if one day they divorce, the property of each party is protected, there is no seizure of joint property or gono-gini.

2. On the debt of each party they make in their marriage, each will be responsible individually.

3. If one party wants to sell the property they do not need to ask permission from their partner (spouse).

4. Likewise with the credit facilities they propose, no longer have to ask permission first from their

\footnotetext{
${ }^{1}$ Nurul miqat and Farida Patittingi. The Rights Of Land In Marriage Agreement Of Miscenegation By Subsquent The Constitusional Court Decision Number 69/PUU-XIII 2015 Based on The Customary Law Perspective. Yustisia Jurnal Hukum. 1 Vol 7 Number 1, 98-108.

${ }^{2}$ K. Wantjik Saleh in Damanhuri H.R, 2012. Segi-segi hukum perjanjian perkawinan harta bersama, Penerbit mandar madju: bandung

${ }^{3}$ Arfin Hamid,2011, Hukum Islam Perspektif Keindonesiaan (sebuah pengantar dalam memahami realitasnya di Indonesia), PT. Umitoha Ukhuwa Grafika, Makassar, hal 73
} 
spouse (husband / wife) in terms of pledging assets listed on the name of one of them.

However, the Marriage Agreement must meet the requirements of Article 29 paragraph 2 of the Marriage Law, which reads:

"The treaty can not be ratified when it violates the boundaries of law, religion and morality.

In the concept of civil law itself, the rights of the legal subjects should be accommodated by other legal subjects. Violations of the rights of other legal subjects will create certain obligations for the offending party. ${ }^{1}$

Likewise in the Law of marriage, many small disputes concerning the rights and duties of one partner, either husband or wife who get discriminatory treatment, or injustice from their spouses. In relation to the marriage agreement it is necessary to make a simple inventory of the application of human rights in the context of marriage in Indonesia.

The context of the application of human rights itself in the human life cycle, in the civil law side ${ }^{2}$ :

a) First, before man is born, that is, not yet as a full legal subject;

b) Secondly, after becoming a legal subject, before adulthood, where all interests are still represented by parents and guardians

c) At the time of maturity and perform activities on their own responsibility

When drawn backward, the development of human rights, globally, actually began after world war 2 with the birth of various international legal instruments on Human Rights, the United Nations charter, particularly Article 55, has given a mandate ti the UN member states to promote and implement the principles fundamental human rights without discrimination based on race, ethnicity, gender, religion and language. ${ }^{3}$

Likewise in the context of marriage law especially in the making of marriage agreement, in the third stage of human rights can be implicated into it. Especially with regard to marriage, in the 1974 UUP of marriage, recognizing the status of men and women as husbands and wives is balanced, equal position without discrimination in activities, which differ only in proportionate rights and obligations, namely the rights and obligations of men as husband and the rights and obligations of women as wives, and all are bound in the bond of the birth and the soul, that the husband and wife should give each other a living and soul.

Likewise in the context of marriage law especially in the making of marriage agreement, in the third stage of human rights can be implicated into it. Especially with regard to marriage, in the 1974 Law of Marriage, recognizing the status of men and women as husbands and wives is balanced, equal position without discrimination in activities, which differ only in proportionate rights and obligations, namely the rights and obligations of men as husband and the rights and obligations of women as wives, and all are bound in the bond of the birth and the soul, that the husband and wife should give each other a living and soul.

In line with the human rights context, the Marriage Law has accommodated the human rights interests of married couples by not giving imbalances to their respective positions. In the marriage agreement which states that the agreement is made on the property of marriage, so that the couple give each other comfort to each other's property, as long as that. a marriage agreement made in accordance with the provisions of Article 29 of the UUP 1974, which reads:

"The agreement can not be ratified when violating the boundaries of law, religion and morals are considered very accommodating of human rights interests, because in principle, every couple who will make a marriage agreement should be concerned with the obligations of moral duty, obligation of punishment, and obligation as a religion.

In the Law of Human Rights of Indonesia, namely in Law No. 39 of 1999 can be inventoried content that regulate civilization that also contains marriage arrangements are matters concerning ekssistensi about humans as the subject of law: ${ }^{4}$

a) In consideration:

1) The existence of recognition of human existence and humanity

2) There is recognition of human dignity and the dignity and harmonization of man and nature

3) The recognition of the inherent natural human rights of humankind is universally and enduringly diminished or deprived by anyone

b) In the torso of law:

a. Recognition of human existence as a dignified legal subject;

1) Human recognition as the subject of the law with basic human freedom

2) Equal recognition of equality and fair treatment in the community, nation and state.

3) Recognition and protection of rights or without discrimination in the eyes of the law,

4) Recognition of the right to life with liberation in fundamental freedoms

5) Recognition of man as a personal person, the same person before the law.

\footnotetext{
${ }^{1}$ Sri redjeki hartono. 2009. "Hak Asasi Manusia Dalam Perspektif Hukum Perdata Sepanjang Masa”.Rafika Aditama: Bandung.

2 Ibid.

${ }^{3}$ Hamid Awaluddin. 2012. HAM, Politik, Hukum Kemunafikan Internasional, Kompas: Jakarta, Hal 10

${ }^{4}$ Ibid
} 
b. Recognition and protection of personal rights, among others:

1) The right to live, the family continues the descendants of self-development

2) Fighting and fighting for their rights

3) Special recognition of the rights of women and children

4) Enforcement of rights and protection of human rights in the differences and needs of indigenous and tribal peoples.

c) The basic obligations in the field of civil law for a person are the rights of another person are:

The right to respected human rights by others morally, ethically, the order of community life, nation and state.

In the Law of Human Rights of Indonesia, namely in Law No. 39 of 1999 can be inventoried content that regulates keperdataan that also contain marriage arrangements, especially the agreement for a husband is the right for others, namely wife.

According to the authors of human rights remains limited by the provisions of the laws, cultures and personalities of each State, in order to ensure the recognition and respect of human rights as well as freedom in morality, public order and the interests of nation and state, marriage law has accommodated the interests of human rights each married couple, especially also to the couple who will make the marriage agreement.

\section{CONCLUSION}

In the context of marriage law in Indonesia especially in human rights can be implicated into it. In the LM of 1974 concerning marriage, the position of men and women as husbands and wives is equal, equal position without discrimination in the conduct of activities, which distinguishes only their rights and obligations proportionally, namely the rights and obligations of men as husbands and the rights and obligations of women as wives, and all are bound in the bond of the birth and the soul, that the husband and wife should give each other a living and inner life, the prospective spouse of the bride and groom to marry should be on the basis of his own will, not forced by other people, the provision should have accommodated human rights. In line with the human rights context, the Marriage Law has accommodated the human rights interests of married couples by not giving imbalances to their respective positions. Establishment of marriage agreement, must be agreement of candidate husband, wife or husband and wife, because of provisions of marriage agreement after the decision of the Constitutional Court, which allows married couples to make a marriage agreement. In the marriage agreement stating that the agreement made against marital property, wives give each other a sense of comfort to each other's property, along it. a marriage agreement made in accordance with the provisions of Article 29 of the LM 1974, which reads: "The agreement can not be ratified when violating the boundaries of law, religion and morals are considered very accommodating of human rights interests, because in principle, every couple who will make a marriage agreement should be concerned with the obligations of moral duty, obligation of punishment, and obligation as a religion.

\section{REFERENCES}

Ahmad Mujahidin. 2009. Hakekat, Konsep Dan Implikasi Dalam Perspektif Hukum Masyarakat, Refika Aditama: Bandung

Arfin Hamid. 2011. Hukum Islam Perspektif Keindonesiaan (sebuah pengantar dalam memahami realitasnya di Indonesia), PT. Umitoha Ukhuwa Grafika: Makassar,

Damanhuri H.R. 2012. Segi-segi hukum perjanjian perkawinan harta bersama, Penerbit mandar madju: bandung

Hamid Awaluddin. 2012. HAM, Politik, Hukum Kemunafikan Internasional, Kompas: Jakarta

Moch. Isnaeni. 2001. Hukum perkawinan Indonesia. Revka Petra Media: Surabaya.

Moch Isnaeni. 2016. Asas Hukum Perkawinan. Refika Petra Media: Surabaya

Mukti Fadjar and yulianto achmad, 2015, dualisme penelitian hukum normative dan empiris, Pustaka Pelajar: Yogyakarta.

Nurul Miqat and Bakhtiar, H.S. 2017. Harmonization Of Uang Panaik as Costumary Term in Bugis-Makassar Ethnic Group and Dowry in Indonesian Marriage System. JL Pol’y \& Globalization, 67, 41.

Nurul miqat and Farida Patittingi. The Rights Of Land In Marriage Agreement Of Miscenegation By Subsquent The Constitusional Court Decision Number 69/PUU-XIII 2015 Based on The Customary Law Perspective. Yustisia Jurnal Hukum. 1 Vol 7 Number 1, 98-108.

Peter Mahmud Marzuki, 2015, penelitian hukum, Prenadamedia Grup: Jakarta

Soetojo Prawirohamidjojo, Pluralisme dalam Perundang-undangan Perkawinan Di Indonesia, 2006, Airlangga University Press, Surabaya

Sri redjeki hartono. 2009. "Hak Asasi Manusia Dalam Perspektif Hukum Perdata Sepanjang Masa".Rafika Aditama: Bandung.

Decision of Constitutional Court Nomor 12./ PUU-V/ 2017

Decision of Constitutional Court Nomor 46/ PUU-VIII/ 2017 